\title{
A comparative study on the anti-angiogenic effects of DNA-damaging and cytoskeletal-disrupting agents
}

\author{
Peace Mabeta $\cdot$ Michael S. Pepper
}

Received: 3 October 2008/Accepted: 26 January 2009/Published online: 12 February 2009

(C) Springer Science+Business Media B.V. 2009

\begin{abstract}
The discovery of molecules with anti-angiogenic properties has led to promising new strategies for the treatment of diseases characterized by excessive new vessel growth, such as cancer and haemangioma. We have assessed the effects of DNA-damaging and cytoskeletaldisrupting agents in vitro on several endothelial cell functions. We report that bleomycin, mitomycin $\mathrm{C}$ and cytoskeletal-disrupting drugs (2-methoxyestradiol, taxol, vincristine, vinblastine, colchicine, nocodazole, and cytochalasin D) exhibit anti-angiogenic activities of varying potency. Bleomycin and the various cytoskeletal-disrupting drugs inhibited endothelial cell migration, while mitomycin $\mathrm{C}$ had a marginal effect. Both DNA-damaging and cytoskeletal-disrupting drugs decreased endothelial cell growth in a dose-dependent manner, and this was accompanied by the induction of apoptosis. The growth inhibitory and apoptotic effects of cytoskeletal-disrupting drugs were the most pronounced. We also show that both classes of drugs inhibited capillary-like tube formation in an assay of
\end{abstract}

P. Mabeta

Department of Physiology, Faculty of Health Sciences, University of Pretoria, Pretoria, South Africa

e-mail: Peace.mabeta@up.ac.za

M. S. Pepper $(\square)$

Department of Immunology, Faculty of Health Sciences, University of Pretoria, P.O. Box 2034, Pretoria 0001,

South Africa

e-mail: michael.pepper@up.ac.za

M. S. Pepper

Département de Médecine Génétique et Développement, University Medical Centre, Geneva, Switzerland in vitro angiogenesis, with cytoskeletal-disrupting agents inhibiting in vitro angiogenesis with greater potency. A targeted approach incorporating several compounds with different mechanisms of action may be useful for the treatment of angiogenesis-dependent diseases such as hemangiomas of infancy.

Keywords Angiogenesis - Hemangioma - Bleomycin · Mitomycin C . Cytoskeletal-disrupting agents .

Angiogenesis · Endothelial cell · Cell growth ·

Cell migration $\cdot$ Tube formation

\section{Introduction}

Hemangiomas are benign vascular tumors frequently encountered in pediatrics, and although benign, may present serious complications [1-3]. Although several approaches have been tried, there is to date no definitive treatment for hemangiomas. Recently however, the effectiveness of intralesional bleomycin was evaluated by the Pretoria Vascular Malformation Study Group in 37 hemangioma patients. Complete resolution or significant improvement was seen in $87 \%$ of patients [2]. Hemangioma development is associated with an imbalance between negative and positive regulators of angiogenesis, and light microscopic examination of haemangioma tissue has demonstrated that the hallmark of a growing hemangioma is proliferating endothelial cells $[4,5]$. Furthermore, vascular endothelial growth factor (VEGF) and basic fibroblast growth factor (bFGF), have been implicated in the pathogenesis of these lesions [6].

The process of angiogenesis is characterized by alterations in at least three endothelial cell functions, each of which is a potential target for anti-angiogenic strategies: (1) modulation of interactions with the extracellular matrix, (2) 
an initial increase and subsequent decrease in migration, and (3) an increase in proliferation, which provides new cells for the growing and elongating vessel [7]. Angiogenesis is also dependent on the suppression of endothelial cell apoptosis [8-10]. The recognition that excessive angiogenesis underlies hemangioma development, offers an opportunity for the development of therapeutic strategies based on the inhibition of angiogenesis.

Therapeutic strategies that target angiogenesis have relied on an understanding of the mechanisms of action of anti-angiogenic molecules and a re-evaluation of conventional chemotherapeutic drugs [11]. With respect to the reexamination of 'classical' anticancer agents, mitomycin $\mathrm{C}$ has previously been shown to inhibit human microvascular endothelial cell growth [12]. However, the anti-angiogenic effects of both mitomycin $\mathrm{C}$ and bleomycin have not been well documented.

Microtubule-disrupting agents (including 2-methoxyestradiol, taxol, vincristine, vinblastine, and colchicine) and the microfilament-disrupting drug, cytochalasin D, have been reported to affect certain elements of the angiogenic process, such as endothelial cell migration and in vitro capillary-like tube formation [13-15].

Previously, drugs with anti-angiogenic activity were developed and tested individually. However, because of the complexity of the angiogenesis process and the number of regulatory molecules involved in blood vessel growth, a multi-drug approach may be required to optimize the antiangiogenic effect of therapy aimed at treating vascular tumors of infancy.

In the present study we evaluated and compared the effects of bleomycin, mitomycin $\mathrm{C}$ and cytoskeletal-disrupting drugs (2-methoxyestradiol, taxol, vincristine, vinblastine, colchicine, nocodazole, and cytochalasin D), on two critical endothelial cell functions namely, endothelial cell migration and growth, which characterize angiogenesis. The effect of these drugs on endothelial cell apoptosis and in vitro angiogenesis were also assessed. To our knowledge, this is the first comparative study undertaken to investigate the anti-angiogenic effects of these drugs under similar conditions.

\section{Materials and methods}

Cell culture

Adrenal cortex-derived bovine microvascular endothelial (BME) cells were maintained in a $37^{\circ} \mathrm{C}$ incubator in a humidified atmosphere containing $5 \% \mathrm{CO}_{2}$. The cells were grown in $\alpha$-modified minimum essential medium ( $\alpha$-MEM) supplemented with $15 \%$ donor calf serum (DCS), penicillin $(500 \mathrm{U} / \mathrm{ml})$, and streptomycin $(100 \mu \mathrm{g} / \mathrm{ml})$.
Cell migration

Confluent monolayers of BME cells in $35 \mathrm{~mm}$ tissue culture dishes were wounded with a blade to mark the initial wound edge. Wounded cultures were washed twice with serum-free $\alpha$-MEM, then serum-free $\alpha$-MEM/ $/ .1 \%$ gelatin and test drugs (bleomycin, mitomycin C, 2-methoxyestradiol (2-ME), taxol, colchicine, nocodazole, and, cytochalasin D) were added at the indicated concentrations (Figs. 1, 2). After $15 \mathrm{~h}$, monolayers were stained with $0.1 \%$ crystal violet in $20 \%$ methanol for 30 min. Fields measuring $1.0 \times 1.4 \mathrm{~mm}$ were selected and further subdivided into smaller fields measuring $100 \mu \mathrm{m}$ each. The fields were then photographed under phase-contrast using a Nikon Diaphot TMD inverted photomicroscope (Nikon, Tokyo, Japan). The total number of cells which had crossed the original wound edge was determined. At least six wells were analyzed from each treatment per experiment. Results were from at least two independent experiments.

\section{Cell growth}

Cell growth studies were performed to assess the effects of test drugs on BME cell growth using a FACScan Analyzer. Briefly, BME cells were seeded into gelatine-coated 24 well-plates at a density of 10,000 cells/well. Cells were grown in $\alpha$-MEM supplemented with 5\% DCS. After $24 \mathrm{~h}$, fresh medium was added together with test drugs (bleomycin, colchicine, 2-methoxyestradiol, and taxol). Control cells were exposed to drug vehicles. Two days later, medium and test drugs were renewed, and further after 2 days, cells were trypsinised and counted in a FACScan Analyzer (Becton-Dickinson, San José, CA). Results represent the mean \pm SEM. Three wells were analyzed for each concentration. Data shown are representative of least two independent experiments.

\section{Analysis of DNA fragmentation}

Confluent BME cell monolayers in $60 \mathrm{~mm}$ tissue culture dishes $\left(1 \times 10^{6}\right.$ cells/plate $)$ were incubated with test drugs/ vehicles for $48 \mathrm{~h}$. At the end of the incubation, floating cells were recovered from culture media by centrifugation, and adherent cells were washed twice with PBS.

Floating and adherent cells were lysed together in $250 \mu \mathrm{l} /$ tissue culture dish of $20 \mathrm{mM}$ Tris- $\mathrm{HCl}, \mathrm{pH} 7.4,5 \mathrm{mM}$ EDTA, pH 7.4, 0.4\% Triton X-100. Cell lysates were centrifuged at $13,000 \mathrm{rpm}$ for $30 \mathrm{~min}$ at $4{ }^{\circ} \mathrm{C}$ to pellet nuclei.

Supernatants were extracted with equal volumes of phenol-chloroform, precipitated with 0.5 volume of $7.5 \mathrm{M}$ ammonium acetate, $\mathrm{pH} 7.5$, and 3 volumes of ethanol, and then centrifuged at $13,000 \mathrm{rpm}$ for $30 \mathrm{~min}$ at $4^{\circ} \mathrm{C}$. Samples were left overnight at $-20^{\circ} \mathrm{C}$. Pellets were resuspended in 
Fig. 1 Effects of bleomycin, mitomycin $\mathrm{C}$, and cytoskeletaldisrupting drugs on BME cell migration. Confluent BME cell monolayers were wounded with a blade to mark the initial wound edge and washed. Cells were then treated with the indicated test substances $(\mathbf{a}-\mathbf{i})$. After $15 \mathrm{~h}$, control and treated cultures were fixed and stained, and subsequently viewed with a light microscope. Within the wound, seven sequential $100 \mu \mathrm{m}$-deep fields parallel to the original wound measuring $1.0 \times 1.4 \mathrm{~mm}$ were delineated from the original normal edge. The total number of cells in each of the field was determined. At least six wells were analyzed from each treatment per experiment. Data shown is from at least two separate experiments per drug and concentration

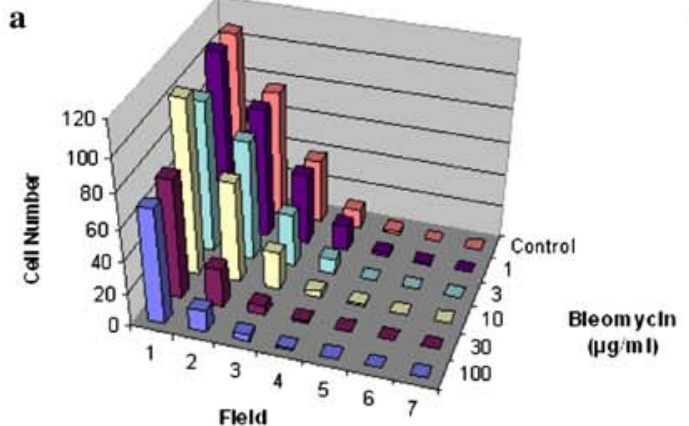

b
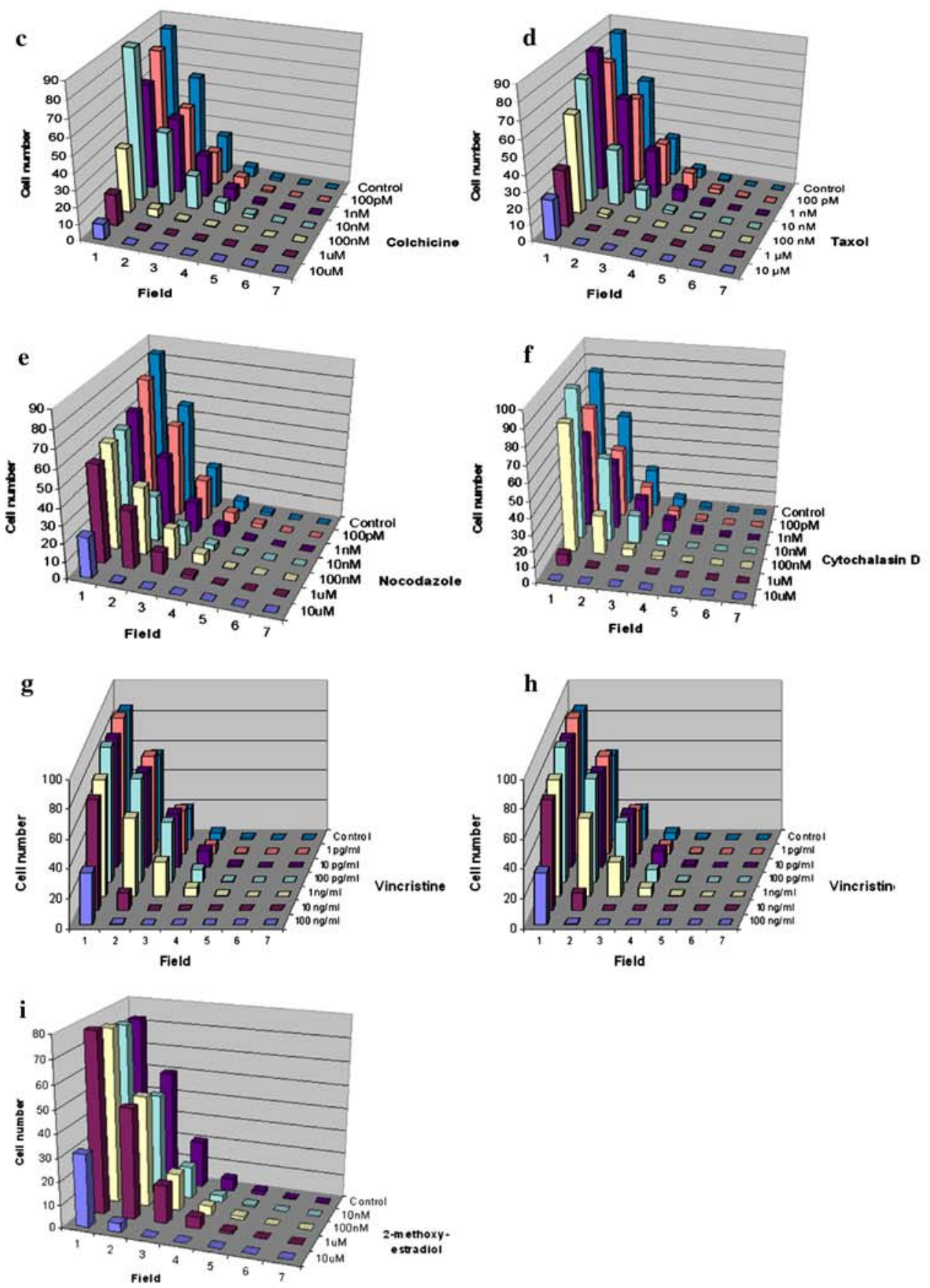

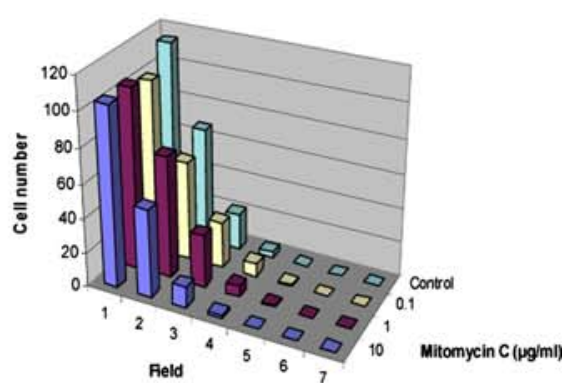


$10 \mathrm{mM}$ Tris-HCl, $\mathrm{pH}$ 8.0,1 mM EDTA, $\mathrm{pH} 8.0$, containing DNase-free pancreatic ribonuclease $(20 \mu \mathrm{g} / \mathrm{ml})$, incubated at $37^{\circ} \mathrm{C}$ for $30 \mathrm{~min}$ and loaded onto $1.8 \%$ agarose gels containing ethidium bromide $(1 \mu \mathrm{g} / \mathrm{ml})$. Samples were electrophoresed at $10 \mathrm{~V} / \mathrm{cm}$ for $2 \mathrm{~h}$. DNA was visualized by UV fluorescence. Results were from at least two separate experiments.

\section{Acridine-orange staining}

Cells were seeded in $35 \mathrm{~mm}$ diameter wells at a density of 20,000 cells per well. After $24 \mathrm{~h}$, BME cells were grown in the presence of the various drug preparations/vehicles for 48 h. Cells were harvested as follows: medium and floating cells were transferred to $15 \mathrm{ml}$ tubes. The rest of the adherent cells were detached with $0.25 \%$ trypsin- $1 \mathrm{mM}$ EDTA. The floating and detached cells from the same sample were pooled together in $15 \mathrm{ml}$ tubes, pelleted by centrifugation at $1,000 \mathrm{rpm}$ for 5 min using a Beckman Model centrifuge, and cell pellets were washed with $1 \mathrm{ml}$ PBS, and subsequently re-suspended in $25 \mu \mathrm{l} \mathrm{PBS}$. Cells were then incubated with $10 \mu \mathrm{g} / \mathrm{ml}$ acridine orange for 5 min. Stained cell suspensions $(10 \mu \mathrm{l})$ were placed on microscope slides and covered with coverslips. Cells were viewed and counted using a Zeiss Axiovert microscope (Carl Zeiss, Jena, Germany) at $400 \times$ magnification. Pictures were taken with a Nikon digital camera. Apoptosis was identified as nuclear chromatin condensation. Randomly selected microscopic fields were examined, and the percentage of cells undergoing apoptosis in each field was determined. Results were expressed as the mean percentage $( \pm \mathrm{SD})$ of cells with evidence of apoptosis. Tests were done in triplicate.
Preparation of collagen gels

The in vitro angiogenesis assay was performed using BME cells as previously described by Montesano and Orci (1987) [16]. Type 1 collagen was solubilized by stirring adult rat tail tendons for $48 \mathrm{~h}$ at $4^{\circ} \mathrm{C}$ in sterile $1: 1000$ (vol/ vol) acetic acid solution (300 $\mathrm{ml}$ for $1 \mathrm{mg}$ of collagen). The resulting solution was filtered through sterile triple gauze and centrifuged at $16,000 \times g$ for $1 \mathrm{~h}$ at $4{ }^{\circ} \mathrm{C}$.

Eight volumes of the supernatant were mixed with 1 volume of $10 \times$ minimum essential medium and 1 volume of sodium bicarbonate $(11.76 \mathrm{mg} / \mathrm{ml})$ in a sterile flask placed on ice, to prevent immediate gelation. The cold mixture was then dispensed into $18 \mathrm{~mm}$ tissue culture wells and allowed to gel for $10 \mathrm{~min}$ at $37^{\circ} \mathrm{C}$.

In vitro angiogenesis assay

BME cells were seeded onto collagen gels at $1.0 \times 10^{5}$ cells/well in $500 \mu \mathrm{l} \alpha$-MEM supplemented with $5 \%$ DCS, and were grown to confluence (3-4 days), at which point treatment with growth factors and/or drugs was begun. Medium and treatments were renewed every second day. After 6 days, cultures were fixed with $2.5 \%$ glutaraldehyde in $100 \mathrm{mM}$ sodium cacodylate buffer ( $\mathrm{pH} \mathrm{7.4).}$ Fixed cultures were photographed for quantification of invasion.

\section{Quantification of invasion}

Three randomly selected fields measuring $1.0 \times 1.4 \mathrm{~mm}$ were photographed in each well at a single level beneath the surface monolayer by phase contrast microscopy.
Fig. 2 Effect of bleomycin, mitomycin $\mathrm{C}$, and cytoskeletaldisrupting drugs on BME cell growth. Cells were seeded at a density of 10,000 cells per well in 24-well culture plates and exposed to test drugs indicated in a-c for 4 days. At termination, drug-treated and control cells were counted following trypsinization using a FACScan analyser. Three wells were analyzed for each concentration. Results represent the mean \pm SEM. Data shown is from least two independent experiments per drug and concentration. * Significant difference between the number of control and treated cells: $P<0.05$
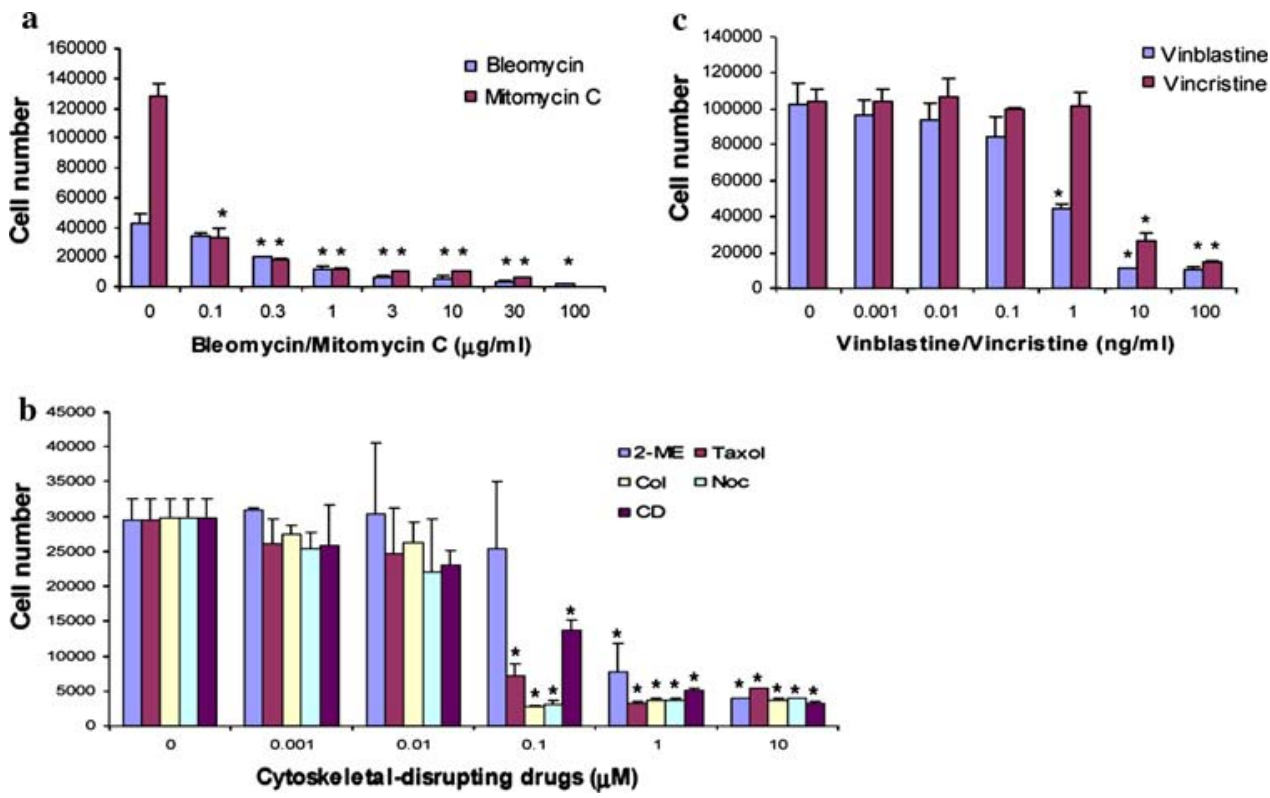
Table 1 Effects of test drugs on endothelial cell growth

\begin{tabular}{lll}
\hline Drug & Cell type & $\mathrm{IC}_{50}$ \\
\hline Bleomycin & BME cells & $0.105 \mu \mathrm{M}$ \\
Bleomycin + bFGF & & $0.053 \mu \mathrm{M}$ \\
Mitomycin C & BME cells & $0.149 \mu \mathrm{M}$ \\
Mitomycin C + bFGF & & $0.180 \mu \mathrm{M}$ \\
2-Methoxyestradiol & BME cells & $0.398 \mu \mathrm{M}$ \\
2-Methoxyestradiol + bFGF & & $0.018 \mu \mathrm{M}$ \\
Taxol & BME cells & $0.040 \mu \mathrm{M}$ \\
Taxol + bFGF & & $0.063 \mu \mathrm{M}$ \\
Vincristine & BME cells & $0.004 \mu \mathrm{M}$ \\
Vincristine + bFGF & & $0.004 \mu \mathrm{M}$ \\
Vinblastine & BME cells & $0.690 \mathrm{nM}$ \\
Vinblastine + bFGF & & $0.900 \mathrm{nM}$ \\
Colchicine & BME cells & $0.032 \mu \mathrm{M}$ \\
Colchicine + bFGF & & $0.017 \mu \mathrm{M}$ \\
Nocodazole & BME cells & $0.031 \mu \mathrm{M}$ \\
Nocodazole + bFGF & & $0.022 \mu \mathrm{M}$ \\
Cytochalasin D & BME cells & $0.063 \mu \mathrm{M}$ \\
Cytochalasin D + bFGF & & $\mathrm{ND}$ \\
\hline Resuls are expresse a & & \\
\hline
\end{tabular}

Results are expressed as $\mathrm{IC}_{50}$ values or the concentration of the respective substance, which resulted in half the numbers of cells being present at the end of the experiment that were obtained in the control. Data is representative of at least two independent experiments per drug and concentration

$N D$ Not determined

$b F G F$ basic fibroblast growth factor
Invasion was quantitated by determining the total additive sprout length in $\mu \mathrm{m} \pm \mathrm{SEM}$, and the results were from at least two separate experiments.

Statistical analysis

Statistics were performed using 1-way ANOVA, and where statistical significance was reached, pair-wise multiple comparisons were made using an ad hoc test (Bonferroni's method). When data were not normally distributed, ANOVA on ranks was performed, followed by pair-wise comparisons, again employing the Bonferroni approach. Significance was designated as $P<0.05$.

\section{Results}

Effects on endothelial cell migration

Bleomycin inhibited $\mathrm{BME}$ cell migration at a dose of $100 \mu \mathrm{g} / \mathrm{ml}$, while no significant inhibition of endothelial cell migration occurred following exposure of cells to mitomycin C (Fig. 1a, b). Inhibition of endothelial cell migration following exposure to colchicine occurred at a dose of $1 \mu \mathrm{M}$ (Fig. 1c) while taxol inhibited cell migration at $0.1 \mu \mathrm{M}$ (Fig. 1d). Nocodazole, cytochalasin D, vinblastine, vincristine and 2-ME inhibited $\mathrm{BME}$ cell migration in a dose-dependent manner (Fig. 1e-i). Both vinblastine and
Fig. 3 Analysis of internucleosomal fragmentation in DNA preparations following exposure to bleomycin, mitomycin $\mathrm{C}$ and cytoskeletaldisrupting drugs for $48 \mathrm{~h}$. Representative experiments are shown

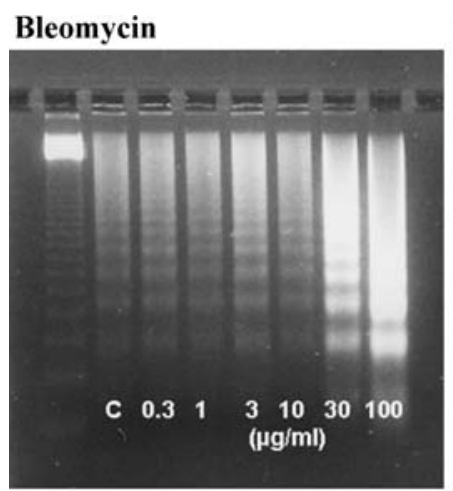

Mitomycin C

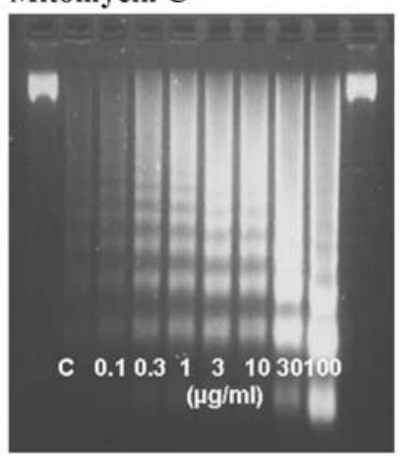

Nocodazole

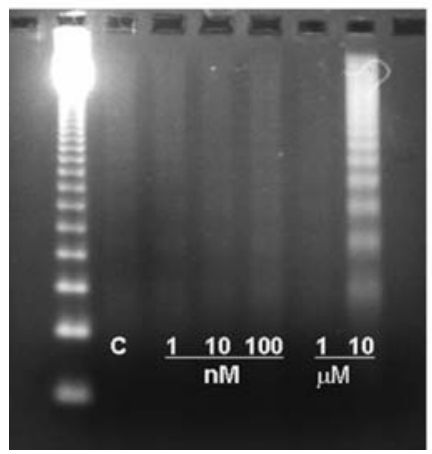

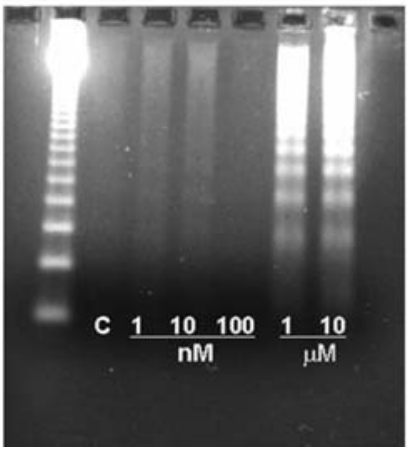

\section{2-Methoxyestradiol}

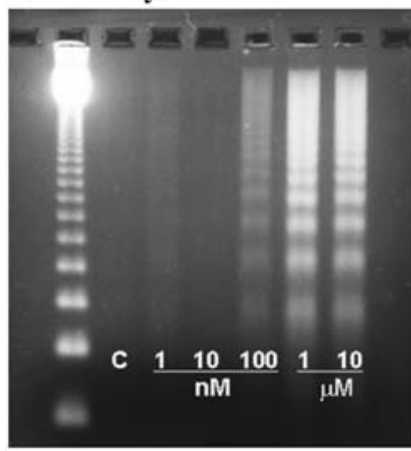

Cytochalasin D

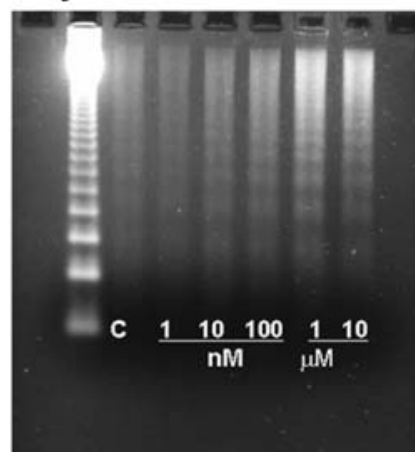


vincristine had a more profound effect by inhibiting cell migration at doses of 0.011 and $0.001 \mu \mathrm{M}$, respectively. The doses at which test drugs induced significant inhibition of endothelial cell migration are summarized in Table 4.

Effects on endothelial cell "growth"

Cell "growth", as determined in the assays performed, measures the absolute number of cells after a given time period under defined conditions. It does not distinguish between cell proliferation and cell death, but is the net result of the two. It is therefore a crude test aimed at determining whether the test substance affects the cells in question, and the cause for any variation needs to be determined in greater detail.

Bleomycin and mitomycin $\mathrm{C}$ inhibited BME cell growth (Fig. 2a), with $\mathrm{IC}_{50}$ values of $0.16 \mu \mathrm{g} / \mathrm{ml}(0.11 \mu \mathrm{M})$ and $0.05 \mu \mathrm{g} / \mathrm{ml}(0.15 \mu \mathrm{M})$, respectively, (Table 1). Bleomycin also inhibited bFGF-induced BME cell growth, with the inhibitory effect being more pronounced at $100 \mu \mathrm{g} / \mathrm{ml}$. The level of 2-ME-induced cell growth inhibition was less than that seen with taxol (Fig. 2b). A maximum inhibitory effect following exposure to 2-ME occurred at a dose of $10 \mu \mathrm{M}$, while taxol exerted a maximum inhibitory effect on endothelial cell growth at a dose of $1 \mu \mathrm{M}$. Colchicine induced a dose-dependent inhibition of BME cell growth with an $\mathrm{IC}_{50}$ of $0.032 \mu \mathrm{M}$ (Table 1). The effects of colchicine on BME cell growth were mimicked by nocodazole $\left(\mathrm{IC}_{50} 0.031 \mu \mathrm{M}\right)$. Cytochalasin $\mathrm{D}$ induced a significant decrease in cell numbers at doses of $1 \mu \mathrm{M}$ and above (Fig. 2b).

Vinblastine and vincristine inhibited growth of endothelial cells in a dose-dependent manner (Fig. 2c); however, vinblastine was more potent as shown by the $\mathrm{IC}_{50}$ values of $0.004 \mu \mathrm{M}$ and $0.690 \mathrm{nM}$, respectively, (Table 1).

Effects on endothelial cell apoptosis

DNA isolated from untreated BME cells was compared with DNA from cells exposed to varying concentrations of the different drugs. Bleomycin induced DNA strand breaks in a dose-dependent manner (Fig. 3). The intensity of the ladders increased with increasing drug concentrations, with the most intense ladders observed following exposure to 30 and $100 \mu \mathrm{g} / \mathrm{ml}$ bleomycin. 2-ME, taxol, Colchicine, nocodazole and cytochalasin D also induced DNA strand breaks (Fig. 3). In 2-ME treated cells, internucleosomal DNA fragmentation was detected only after exposure to the highest dose $(10 \mu \mathrm{M})$, while colchicine and taxol induced DNA strand breaks at doses of only $100 \mathrm{nM}$.

The percentage of acridine orange labeled-BME cells was increased in cultures exposed to the various test drugs (Table 2), indicating that they induced apoptosis.
Table 2 Induction of apoptosis in BME cells

\begin{tabular}{|c|c|}
\hline & $\%$ Acridine orange-labeled cells \\
\hline Control & $5.92 \pm 4.28$ \\
\hline \multicolumn{2}{|l|}{ Bleomycin } \\
\hline $0.1 \mu \mathrm{g} / \mathrm{ml}$ & $11.26 \pm 9.62$ \\
\hline $10 \mu \mathrm{g} / \mathrm{ml}$ & $21.03 \pm 11.61 *$ \\
\hline $100 \mu \mathrm{g} / \mathrm{ml}$ & $41.72 \pm 16.35^{*}$ \\
\hline \multicolumn{2}{|l|}{ Mitomycin } \\
\hline $0.1 \mu \mathrm{g} / \mathrm{ml}$ & $22.55 \pm 18.60^{*}$ \\
\hline $1 \mu \mathrm{g} / \mathrm{ml}$ & $33.76 \pm 18.21^{*}$ \\
\hline $10 \mu \mathrm{g} / \mathrm{ml}$ & $58.10 \pm 20.42 *$ \\
\hline \multicolumn{2}{|l|}{ Colchicine } \\
\hline $0.01 \mu \mathrm{M}$ & $6.21 \pm 4.02$ \\
\hline $1 \mu \mathrm{M}$ & $33.52 \pm 11.26^{*}$ \\
\hline $10 \mu \mathrm{M}$ & $31.05 \pm 9.65^{*}$ \\
\hline \multicolumn{2}{|l|}{ Nocodazole } \\
\hline $0.01 \mu \mathrm{M}$ & $12.53 \pm 9.36$ \\
\hline $1 \mu \mathrm{M}$ & $43.87 \pm 9.75^{*}$ \\
\hline $10 \mu \mathrm{M}$ & $40.25 \pm 8.15^{*}$ \\
\hline \multicolumn{2}{|l|}{ Taxol } \\
\hline $0.01 \mu \mathrm{M}$ & $17.82 \pm 6.22 *$ \\
\hline $1 \mu \mathrm{M}$ & $45.37 \pm 10.80^{*}$ \\
\hline $10 \mu \mathrm{M}$ & $44.00 \pm 8.01^{*}$ \\
\hline \multicolumn{2}{|l|}{ 2-ME } \\
\hline $0.01 \mu \mathrm{M}$ & $18.57 \pm 8.05^{*}$ \\
\hline $1 \mu \mathrm{M}$ & $32.81 \pm 12.50^{*}$ \\
\hline $10 \mu \mathrm{M}$ & $52.21 \pm 10.02 *$ \\
\hline \multicolumn{2}{|l|}{ Vincristine } \\
\hline $0.001 \mathrm{ng} / \mathrm{ml}$ & $5.92 \pm 6.10$ \\
\hline $0.1 \mathrm{ng} / \mathrm{ml}$ & $5.87 \pm 4.25$ \\
\hline $10 \mathrm{ng} / \mathrm{ml}$ & $27.26 \pm 11.20^{*}$ \\
\hline \multicolumn{2}{|l|}{ Vinblastine } \\
\hline $0.001 \mathrm{ng} / \mathrm{ml}$ & $6.04 \pm 8.22$ \\
\hline $0.1 \mathrm{ng} / \mathrm{ml}$ & $12.01 \pm 8.75$ \\
\hline $10 \mathrm{ng} / \mathrm{ml}$ & $37.20 \pm 11.26^{*}$ \\
\hline
\end{tabular}

Confluent monolayers of BME cells were exposed to the agents indicated above, and apoptosis (acridine orange labeling) was determined after $48 \mathrm{~h}$. Values are the mean \pm SD. Results are pooled from at least three separate experiments per drug and concentration. An average of 12 fields was analyzed per treatment dose in each experiment. * Significant difference between control and drug-treated cells: $P<0.05$

Effects on in vitro angiogenesis

Control untreated BME cells formed a monolayer on the surface of 3-dimensional collagen gels (Fig. 4a) with a cobblestone appearance, while BME cells treated with a combination of $10 \mathrm{ng} / \mathrm{ml} \mathrm{bFGF}$ and $30 \mathrm{ng} / \mathrm{ml}$ VEGF invaded the underlying gel and organized into branching cords inside the collagen matrix (Fig. 4b); few such cords were observed in cultures treated with bleomycin alone or 
with a combination of bFGF/VEGF and bleomycin (Fig. 4c-d).

There were no endothelial cell cords in cultures exposed to colchicines or 2-ME or only (Fig. 4e, g); however, colchicine- and bleomycin-treated cells appeared similar in morphology to control cells, while 2-ME-treated cells appeared polygonal in morphology (e). Quantitative analysis of in vitro tube formation showed that bleomycin, mitomycin $\mathrm{C}$, colchicine, 2-ME, nocodazole, cytochalasin $\mathrm{D}$ and taxol inhibited bFGF-induced BME cell cord formation (Fig. 5a-d; Tables 3, 4).

\section{Discussion}

Herein we describe studies undertaken to compare the antiangiogenic effects of DNA-damaging drugs and agents that affect cytoskeletal dynamics. Our observations revealed that bleomycin, a DNA-damaging chemotherapeutic drug, as well as cytoskeletal-disrupting agents (2-methoxyestradiol, taxol, vincristine, vinblastine, colchicine, nocodazole, and cytochalasin D) inhibited BME cell migration. However, the inhibitory effects of cytoskeletal-disrupting drugs on endothelial cell migration were more pronounced. In addition to endothelial cell migration, angiogenesis is characterized by endothelial cell growth, sometimes uncontrolled, as well as capillary-like tube formation. Therefore further studies on the anti-angiogenic effects of test drugs were evaluated using assays of cell growth and in vitro tube formation.

Cell "growth" studies revealed a dose-dependent reduction in the percentage of viable BME cells in bleomycin- and mitomycin C-treated cultures. Cytoskeletaldisrupting drugs, with the exception of 2-ME, caused a
Fig. 4 Effects of bleomycin, colchicine, 2 methoxyestradiol (2ME) and Taxol on BME cells grown on collagen gel. Cells seeded on top of type I collagen gel were exposed to drugs in the presence or absence of bFGF for 6 days. Medium and treatments were renewed every second day. At termination, cultures were fixed with $2.5 \%$ glutaraldehyde; three randomly selected fields measuring $1.0 \times 1.4 \mathrm{~mm}$ were then photographed in each well at a single level beneath the surface monolayer by phase contrast microscopy. Results are from at least two separate experiments per drug and concentration. Bar $=100 \mu \mathrm{m}$
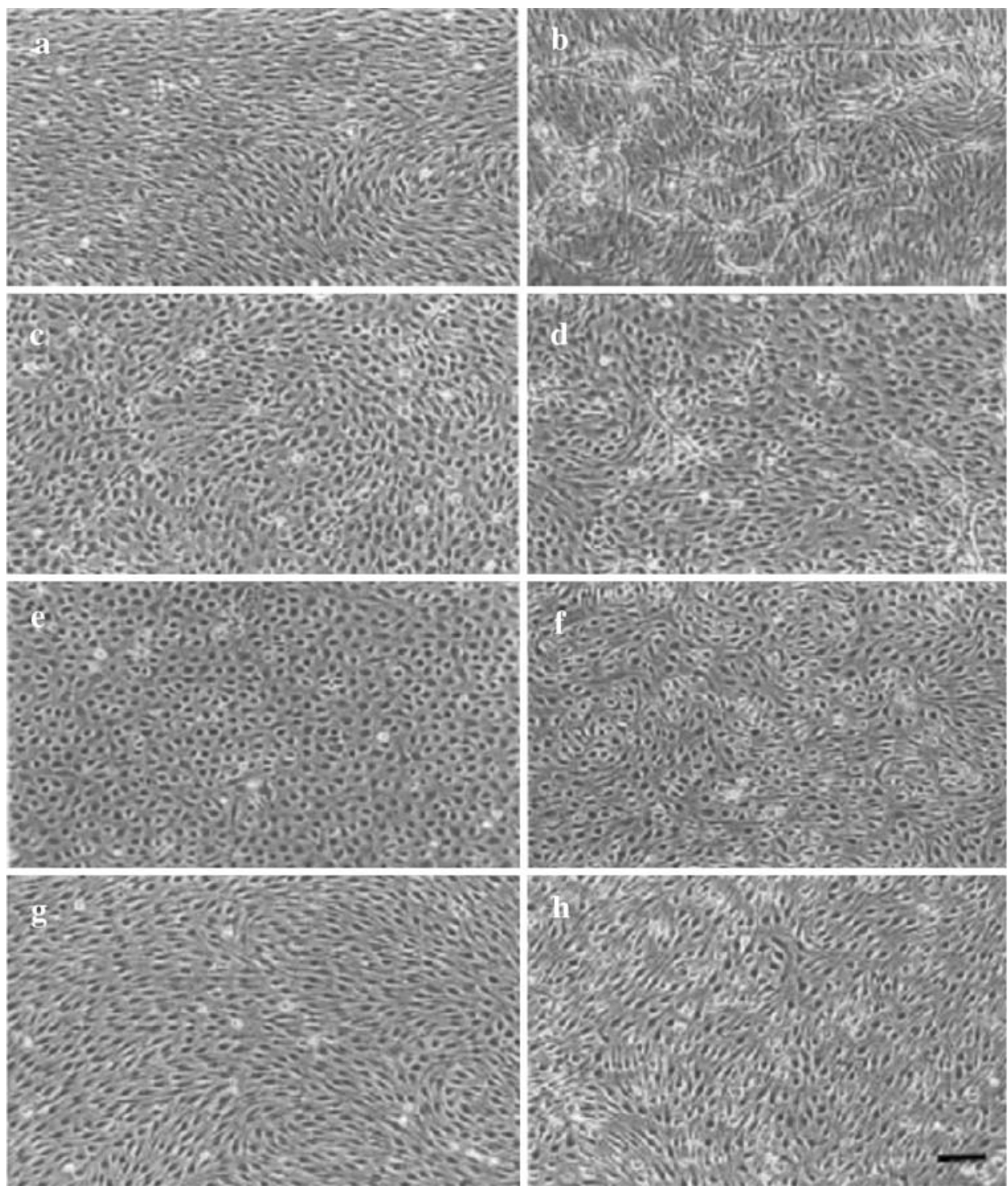

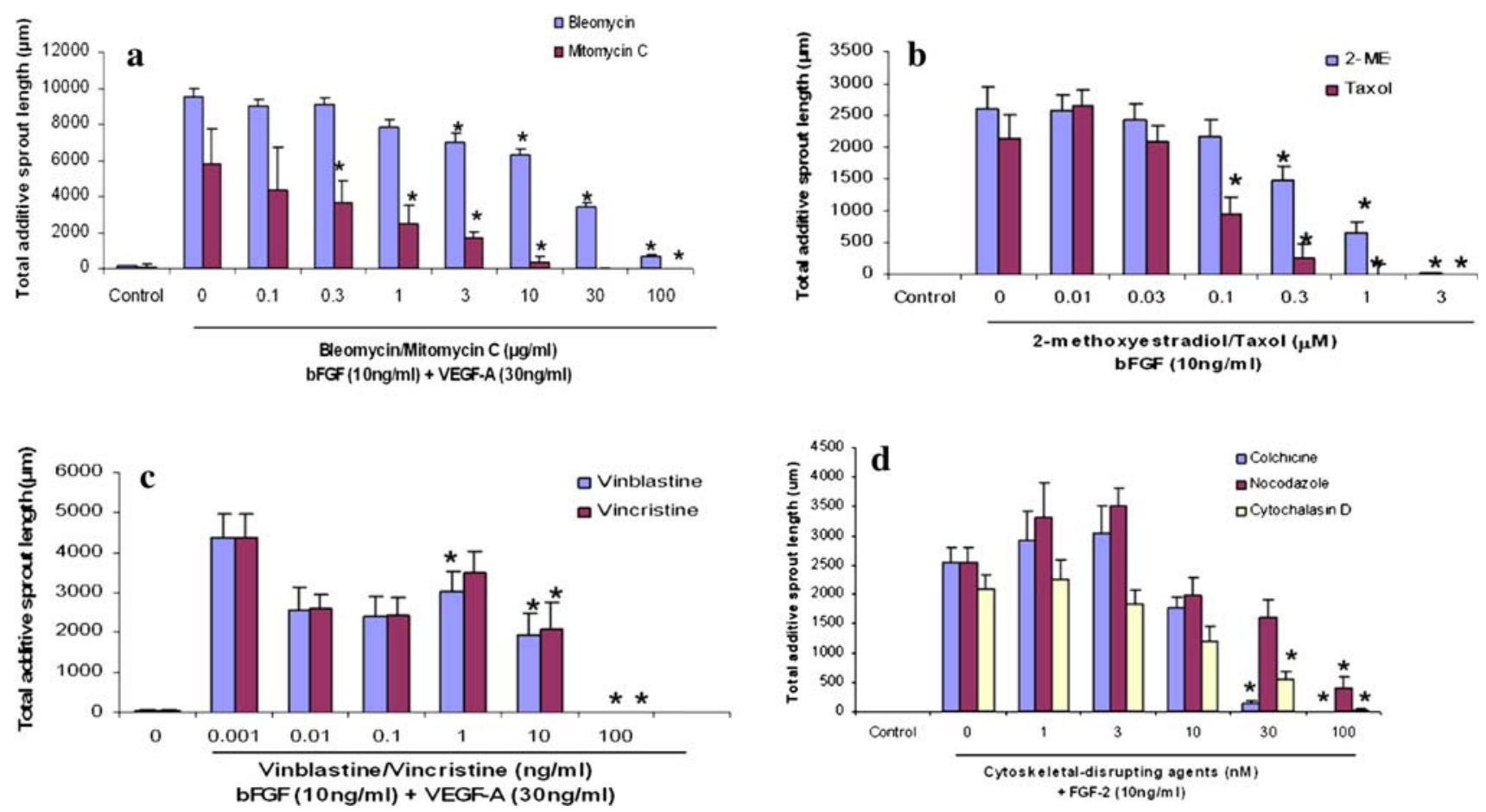

Fig. 5 Quantitative analysis of the effects of bleomycin, mitomycin $\mathrm{C}$, and cytoskeletal-disrupting drugs on in vitro angiogenesis. BME cells were seeded on collagen gel in the presence of bFGF alone or bFGF and test drugs. After 6 days, invasion was quantitated by determining the total additive sprout length in $\mu \mathrm{m} \pm \mathrm{SEM}$, and

Table 3 Quantitative analysis of the effects of test drugs on in vitro angiogenesis

\begin{tabular}{llr}
\hline Drug & Cell type & \multicolumn{1}{l}{$\mathrm{IC}_{50}$} \\
\hline Bleomycin & BME cells & $11.850 \mu \mathrm{M}$ \\
Mitomycin C & BME cells & $2.340 \mu \mathrm{M}$ \\
2-Methoxyestradiol & BME cells & $0.400 \mu \mathrm{M}$ \\
Taxol & BME cells & $0.010 \mu \mathrm{M}$ \\
Vincristine & BME cells & $0.860 \mathrm{nM}$ \\
Vinblastine & BME cells & $0.870 \mathrm{nM}$ \\
Colchicine & BME cells & $0.016 \mu \mathrm{M}$ \\
Nocodazole & BME cells & $0.017 \mu \mathrm{M}$ \\
Cytochalasin D & BME cells & $0.017 \mu \mathrm{M}$
\end{tabular}

Results are presented as $\mathrm{IC}_{50}$ values, the drug concentration at which $50 \%$ inhibition of capillary-like tube formation was observed. Data shown is from at least two independent experiments per drug and concentration

reduction in BME cell numbers in a dose-dependent manner, and with greater potency than bleomycin and mitomycin C. Bleomycin, 2-ME, colchicine and nocodazole induced a more pronounced reduction in cell numbers in bFGF-treated BME cells than when added alone. Therefore, cytokine stimulated BME cells appear to be more susceptible to the growth inhibitory effects of these

results are from at least two separate experiments. Two wells were analyzed for each concentration. Data shown is from at least two independent experiments per drug and concentration. *Significant difference in total additive sprout length between untreated $(0 \mu \mathrm{g} / \mathrm{ml})$ and drug-treated cells: $P<0.05$

drugs. Previous reports suggest that bFGF may have a role in the development of various tumors, including hemangiomas of infancy [5].

Bleomycin has recently been employed in the treatment of juvenile hemangiomas, with promising results [17-19]. Initially, the effectiveness of bleomycin in inducing hemangioma regression was attributed to the sclerosing effect of the drug on the vascular endothelium [18]. More recently however, it was shown that bleomycin prevents human hemangioma growth in vitro by inhibiting neovessel growth [20]. Bleomycin's antiproliferative effects on growth factor-stimulated endothelial cells could be partly responsible for its ability to inhibit hemangioma growth in patients.

Also, the ability of 2-ME, colchicine and nocodazole to inhibit endothelial cell growth in the presence of this potent angiogenic growth factor may be translated in the clinical setting to enable effective growth inhibition in juvenile hemangiomas.

To determine the mode by which these test drugs decreased cell numbers, their effect on apoptosis was assessed. When DNA extracted from BME cells treated with bleomycin, mitomycin, 2-methoxyestradiol, taxol, colchicine, nocodazole, or cytochalasin D was analyzed using gel electrophoresis, characteristic internucleosomal "ladders" of DNA fragments were found. These ladders 
Table 4 A summary of the effects of test drugs on the different parameters measured

\begin{tabular}{|c|c|c|c|c|}
\hline Drug & $\begin{array}{l}\text { Cell growth } \\
\left(\mathrm{IC}_{50}\right)\end{array}$ & Cell migration $^{\mathrm{a}}$ & Apoptosis $^{\mathrm{b}}$ & In vitro angiogenesis $\left(\mathrm{IC}_{50}\right)$ \\
\hline Bleomycin & $0.105 \mu \mathrm{M}$ & $66.7 \mu \mathrm{M}$ & $6.677 \mu \mathrm{M}$ & $11.850 \mu \mathrm{M}$ \\
\hline Mitomycin C & $0.149 \mu \mathrm{M}$ & NI & $2.990 \mu \mathrm{M}$ & $2.340 \mu \mathrm{M}$ \\
\hline 2-Methoxyestradiol & $0.398 \mu \mathrm{M}$ & $10.0 \mu \mathrm{M}$ & $0.010 \mu \mathrm{M}$ & $0.400 \mu \mathrm{M}$ \\
\hline Taxol & $0.040 \mu \mathrm{M}$ & $0.100 \mu \mathrm{M}$ & $0.010 \mu \mathrm{M}$ & $0.010 \mu \mathrm{M}$ \\
\hline Vincristine & $0.004 \mu \mathrm{M}$ & $0.001 \mu \mathrm{M}$ & $0.011 \mu \mathrm{M}$ & $0.860 \mathrm{nM}$ \\
\hline Vinblastine & $0.690 \mathrm{nM}$ & $0.011 \mu \mathrm{M}$ & $0.011 \mu \mathrm{M}$ & $0.870 \mathrm{nM}$ \\
\hline Colchicine & $0.032 \mu \mathrm{M}$ & $0.100 \mu \mathrm{M}$ & $1.000 \mu \mathrm{M}$ & $0.016 \mu \mathrm{M}$ \\
\hline Nocodazole & $0.031 \mu \mathrm{M}$ & $10.0 \mu \mathrm{M}$ & $1.000 \mu \mathrm{M}$ & $0.017 \mu \mathrm{M}$ \\
\hline Cytochalasin D & $0.063 \mu \mathrm{M}$ & $0.100 \mu \mathrm{M}$ & ND & $0.017 \mu \mathrm{M}$ \\
\hline
\end{tabular}

${ }^{a}$ Dose at which significant inhibition of cell migration was observed

${ }^{b}$ Dose at which a significant number of BME cells were induced to undergo apoptosis

$N I$ No inhibition of cell migration was observed at tested doses

$N D$ Not determined

were not observed in control samples. Results from cultures that were exposed to vincristine and vinblastine were inconclusive. Internucleosomal DNA fragmentation is a biochemical indicator of apoptosis [21, 22].

In addition to DNA fragmentation, chromatin condensation is an early and relatively unequivocal hallmark of apoptosis [22]. Therefore, drug-induced apoptosis was further evaluated using the acridine orange stain, which assesses chromatin condensation. We found that the test drugs, including vinca alkaloids (vincristine and vinblastine), increased acridine orange staining of BME cell nuclei, indicating that the drugs induced BME cell apoptosis. Inhibition of apoptosis (and the promotion of endothelial cell survival) is important in the process of angiogenesis. Several anti-angiogenic agents such as angiostatin and endostatin have been reported to inhibit angiogenesis in part by inducing endothelial cell apoptosis $[8,9]$. Results from this study further indicate that these drugs have apoptotic activity which is likely to contribute to their anti-angiogenic effect.

For in vitro angiogenesis studies, bovine microvascular endothelial (BME) cells were cultured on the surface of 3dimensional type 1 collagen gels. Under control conditions, BME cells remain on the surface of the gels, forming a confluent monolayer. Growth factors (bFGF alone or $\mathrm{bFGF}+\mathrm{VEGF}$ ) induced BME cells to invade the underlying collagen matrix, within which they form networks of capillary-like tubular structures, a phenomenon that closely mimics the angiogenic process occurring in vivo. In previous studies, it was shown that bFGF and VEGF induce BME cell invasion and tube formation in a collagen gel invasion assay [23-25].
Our findings indicate that cytoskeletal-disrupting agents tested (taxol, vincristine, vinblastine, colchicine, nocodazole and cytochalasin D), inhibit angiogenesis in vitro with more potency than the DNA-damaging drugs, with the exception of 2-ME. The vinca alkaloids, vincristine and vinblastine, were the most potent inhibitors of angiogenesis, followed by taxol.

Taxol has been reported to exhibit anti-angiogenic activity in vitro at doses that are well below the maximum tolerated dose. In addition, vincristine, vinblastine, colchicine and nocodazole were shown in this study to inhibit angiogenesis at noncytotoxic doses.

In general, the anti-proliferative effects induced by most chemotherapeutic agents are associated with cell cycle arrest and induction of apoptosis. Interestingly, vincristine, vinblastine, colchicine and nocodazole induced an inhibition of cell growth at doses which did not result in significant apoptosis. At these cytostatic doses, the drugs inhibited angiogenesis in vitro.

A few case studies have reported on the use of vincristine to treat hemangiomas, although its mechanism of action has not been reported. It seems plausible that the positive results observed in hemangioma patients following treatment with vincristine may be due in part to its potent anti-angiogenic activity.

Furthermore, vinblastine, colchicine, nocodazole as well as taxol may have potential in the treatment of juvenile hemangiomas, as they are more potent at inhibiting angiogenesis than bleomycin. Further studies will focus on the effects of combinations of these drugs on angiogenesis in vitro and on hemangioma development in experimental models in vivo. 
Acknowledgments We would like to thank Corinne Di Sanza and Mireille Quayzin for excellent technical assistance. We also thank Prof Piet Becker, Biostats Unit, Medical Research Council, for assistance with statistical analysis. This work was funded by the Swiss National Science Foundation (grant no. 3100-064037.00 to MSP) and the National Research Foundation.

\section{References}

1. Enjolras O (1997) Management of hemangiomas. Dermatol Nurs 9:11-17

2. Muir T, Kirsten M, Fourie P et al (2004) Intralesional bleomycin injection (IBI) treatment for haemangiomas and congenital vascular malformations. Pediatr Surg Int 19:766-773. doi:10.1007/ s00383-003-1058-6

3. Hasan Q, Tan ST, Gush J, Peters SG, Davis PF (2000) Steroid therapy of a proliferating hemangioma: histochemical and molecular changes. Pediatrics 105:117-121. doi:10.1542/peds. 105.1.117

4. Pepper MS (1997) Manipulating angiogenesis. From basic science to the bedside. Arterioscler Thromb Vasc Biol 17:605-919

5. Mulliken JB, Glowacki J (1982) Hemangiomas and vascular malformations in infants and children: a classification based on endothelial characteristics. Plast Reconstr Surg 69:412-420

6. Takahashi K, Mulliken JB, Kozakewich HPW, Rogers RA, Folkman J, Ezekowitz RAB (1994) Cellular markers that distinguish the phases of hemangioma during infancy and childhood. $\mathrm{J}$ Clin Invest 93:2357-2364. doi:10.1172/JCI117241

7. Pepper MS (2001) Role of matrix metalloproteinase and plasminogen activator-plasmin system in angiogenesis. Arterioscler Thromb Vasc Biol 21:1104-1117. doi:10.1161/hq0701.093685

8. Folkman J (2003) Angiogenesis and apoptosis. Semin Cancer Biol 13:159-167. doi:10.1016/S1044-579X(02)00133-5

9. Polunovsky VA, Wendt $\mathrm{CH}$, Ingber DH, Peterson MS, Bitterman PB (1994) Induction of endothelial cell apoptosis by $\mathrm{TNF} \alpha$ : modulation by inhibitors of protein synthesis. Exp Cell Res 214:584-594. doi:10.1006/excr.1994.1296

10. Holmgren LL, Garcia I, Jimenez B, Mandriota SJ, Borlat F, Sim BKL et al (1998) Multiple forms of angiostatin induce apoptosis in endothelial cells. Blood 92:4730-4741

11. Pandya NM, Dhalla NS, Santani DD (2006) Angiogenesis-a new target for future therapy. Vascul Pharmacol 44:265-274. doi: 10.1016/j.vph.2006.01.005

12. Dirix LY, Libura M, Vermeulen PB et al (1997) In vitro toxicity studies with mitomycins and bleomycin on endothelial cells.
Anticancer Drugs 8:859-868. doi:10.1097/00001813-19971000000007

13. Ingber DE, Prusty D, Sun Z et al (1995) Cell shape, cytoskeletal mechanics, and cell cycle control in angiogenesis. J Biomech 28:1471-1484. doi:10.1016/0021-9290(95)00095-X

14. Klauber N, Parangi S, Flynn E et al (1997) Inhibition of angiogenesis and breast cancer in mice by the microtubule inhibitors 2methoxyestradiol and taxol. Cancer Res 57:81-86

15. Stafford SJ, Schwimer J, Anthony CT et al (2005) Colchicine and 2-methoxyestradiol inhibit human angiogenesis. J Surg Res 125:104-108. doi:10.1016/j.jss.2004.11.017

16. Montesano R, Orci L (1985) Tumor-promoting phorbol esters induce angiogenesis in vitro. Cell 42:469-477. doi:10.1016/00928674(85)90104-7

17. Sarihan H, Mocan H, Yildiz K, Abes M, Akyazici R (1997) A new treatment with bleomycin for complicated cutaneous hemangiomas in children. Eur J Pediatr Surg 7:158-162. doi: $10.1055 / \mathrm{s}-2008-1071080$

18. Kullendorf CM (1997) Efficacy of bleomycin treatment for symptomatic hemangiomas in children. Pediatr Surg Int 12:526528. doi:10.1007/BF01258718

19. Pienaar C, Graham R, Geldenhuys S, Hudson DA (2006) Intralesional bleomycin for the treatment of hemangiomas. Plast Reconstr Surg 117:221-226. doi:10.1097/01.prs.0000194906. 61805.b0

20. Mabeta P, Davis PF (2008) The mechanism of bleomycin in inducing haemangioma regression. S Afr Med J 98:538-539

21. Catchpoole DR, Stewart BW (1995) Formation of apoptotic bodies is associated with internucleosomal DNA fragmentation during drug-induced apoptosis. Exp Cell Res 216:169-177. doi: 10.1006/excr.1995.1021

22. Elmore S (2007) Apoptosis: a review of programmed cell death. Toxicol Pathol 35:495-516. doi:10.1080/01926230701320337

23. Mandriota SJ, Pepper MS (1997) Vascular endothelial growth factor-induced in vitro angiogenesis and plasminogen activator expression are dependent on endogenous basic fibroblast growth factor. J Cell Sci 110:2293-2302

24. Pepper MS, Hazel SJ, Humpel M, Schleuning W-D (2004) 8Prenylnaringenin, a novel phytoestrogen, inhibits angiogenesis in vitro and in vivo. J Cell Physiol 199:98-107. doi:10.1002/jcp. 10460

25. Pepper MS, Ferrara N, Orci L, Montesano R (1992) Potent synergism between vascular endothelial growth factor and basic fibroblast growth factor in the induction of angiogenesis in vitro. Biochem Biophys Res Commun 189:824-831. doi:10.1016/0006291X(92)92277-5 